\title{
GYPSIES OF THE BELARUSIAN PROVINCES AND LAND MANAGEMENT POLICY AT THE TURN OF THE 1830s-1840s
}

\author{
Vladimir N. Shaidurov \\ Pushkin Leningrad State University. St. Petersburg, Russia. Email: s-w-n[at]mail.ru
}

\begin{abstract}
At the turn of the 18th-19th centuries, the tsarist government in Russia faced the Gypsy question in the context of implementation of the society homogenization policy. There were campaigns initiated to fight with Gypsy vagrancyduring the 1770s1810s, the primary target of which was to modernize the Gypsies of the Russian Empire and turn them into a constant component of rural or urban societies. However, despite the repressive tools included, these measures did not effect the desired result. The purpose of the present paper is to study the relationship between the Belarusian Gypsies and the authorities when it came to acquisition of land and set up of arable farms in the late 1830s-early 1840s as part of implementation of the subsequent campaign to turn the Gypsies of Russia into a settled population. The basis of the research were archival materials from the fund of the Second Department of the Ministry of State Property of the Russian State Historical Archive (St. Petersburg). Studying of various historical sources revealed the features of implementation of the decree of Nicholas I (1839) in the Belarusian provinces. Despite the willingness of the local gypsy camps to adopt the sedentary life, they faced various forms of latent chauvinism at the local level: officials sabotaged orders from St. Petersburg; peasants did not want to accept Gypsies into their societies. The article is intended for specialists in the history of the Roma and the national politics in the Russian Empire.
\end{abstract}

\section{Keywords}

Russian Empire; Belarus; Grodno province; Mogilev province; Gypsies; national politics; Nicholas I; Kiselev P. D.; vagrancy; sedentary lifestyle 


\section{ЦЫГАНЕ БЕЛОРУССКИХ ГУБЕРНИЙ И ЗЕМЛЕУСТРОИТЕЛЬНАЯ ПОЛИТИКА НА РУБЕЖЕ 1830-1840-Х ГГ.}

\section{Шайдуров Владимир Николаевич}

Ленинградский государственный университет им. А.С. Пушкина. Санкт-Петербург, Россия. Email: s-w-n[at]mail.ru

\section{Аннотация}

На рубеже XVIII-XIX в. перед царским правительством в России в условиях реализации политики гомогенизации общества встал цыганский вопрос. В течение 1770-1810-х гг. были инициированы кампании по борьбе с цыганским бродяжничеством, с целью модернизации уклада цыган Российской империи и превращения их в постоянную часть сельских или городских обществ. Однако эти мероприятия, несмотря на включение в них репрессивного инструментария, не принесли желаемого результата. Целью данной статьи является изучение взаимоотношений белорусских цыган и администрации в вопросе обретения земли и устройства земледельческого хозяйства в конце $1830-\mathrm{x}$ - начале 1840 -х гг. в рамках реализации очередной кампании по превращению цыган России в оседлое население. Основой для исследования стали архивные материалы из фонда Второго Департамента Министерства государственных имуществ Российского государственного исторического архива (Санкт-Петербург). Анализ различных исторических источников позволил выявить особенности реализации указа Николая I (1839 г.) в белорусских губерниях. Автор пришел к выводу о том, что, несмотря на готовность местных цыганских таборов перейти к оседлому образу жизни, они сталкивались с различными формами латентного шовинизма на местном уровне: чиновники саботировали распоряжения из Санкт-Петербурга, крестьяне не хотели принимать цыган в свои общества. Статья рассчитана на специалистов по истории цыган и национальной политики в Российской империи.

\section{Ключевые слова}

Российская империя; Беларусь; Гродненская губерния; Могилевская губерния; цыгане; национальная политика; Николай I; Киселев П.Д.; бродяжничество; оседлый образ жизни

Это произведение доступно по дицензии Creative Commons «Attribution» («Атрибуция») 4.0 Всемирная 


\section{ВВЕДЕНИЕ}

В XVIII в. тысячи цыган стали подданными Российской империи. Уже в этот период цыганский мир страны не отличался единообразием. Он состоял из различных по своему языку, традициям, вероисповеданию, хозяйственным занятиям цыганских групп, среди которых самыми многочисленными были ингерманландские цыгане, цыгане белорусских губерний, Крыма. Одной из объединяющих характеристик этих сообществ являлся полукочевой образ жизни с постепенным переходом к оседлости. Во второй половине XIX в. цыганский мир России пополнили группы центральноазиатских цыган (люли, парья, кавол и др.) (Деметер \& Черных, 2018, с. 99) и кэлдэрары, ведущие преимущественно кочевой образ жизни (Там же, с. 94-95). Миграционные процессы, в которые были вовлечены цыгане, способствовали формированию новых этнодисперсных групп в пограничных регионах. Так, в приграничье Могилевщины, Псковщины и Смоленщины возникли региональные группы «псковска рома» и «смоленска рома». На рубеже XVIII-XIX вв. в Сибири сформировалась еще одна группа - «сибирска рома» (Шайдуров и др., 2020, с. 130-142). Но для администрации все эти различия являлись несущественным фактором. В основе отношения аппарата к цыганам лежал традиционный конфессиональный признак. Принадлежность их к православной, лютеранской либо мусульманской общинам ограждала от проведения сегрегационной политики. В этом отношении они отличались, например, от еврейского населения Российской империи.

\section{МЕТОДЫ И ИСТОЧНИКИ}

Целью данной статьи является изучение взаимоотношений белорусских цыган и администрации в вопросе обретения земли и устройства земледельческого хозяйства в конце 1830-х - начале 1840-х гг. в рамках реализации очередной кампании по превращению цыган России в оседлое население.

В основу исследования заложены принципы теорий модернизации и фронтира. В условиях перехода от традиционного к индустриальному обществу русское правительство стремилось избавиться от некоторых анахронизмов в виде кочевничества. То, что было традиционным и допускалось для десятков тысяч подданных в Сибири и Центральной Азии, было нетерпимо в ее Европейской части. Продолжалась реализация Петровской концепции построения регулярного государства, в котором каждый член занимал свое строго опреде- 
ленное место. Цыгане должны были стать неотъемлемой частью сельской общины либо городского сообщества.

Автором были использованы преимущественно материалы из Российского государственного исторического архива, которые впервые вводятся в научный оборот.

\section{ОБСУЖДЕНИЕ}

История цыган в России и государственной политики в отношении цыган изучена фрагментарно и поверхностно. Первые публикации о цыганах на территории Российской империи относятся к первой половине XIX в. Среди авторов следует выделить польского историка и публициста Т. Чацкого (Czacki, 1807a, 1807b, 1810, 1835, 1845) и правоведа, профессора права в нескольких российских университетах И. Даниловича (Данилович, 1826). Объемная работа последнего должна была познакомить русского читающего обывателя с цыганским миром, который, наряду с еврейским, стал неотъемлемой частью внутренней политики России. И. Данилович, проанализировав крайне немногочисленный корпус русских законов в отношении цыган, одним из первых пришел к выводу о том, что политика Екатерины II и ее последователей на рубеже XVIII-XIX вв. своим либеральным характером выгодно отличалась от действий властей Англии, Швеции, Австрии, Пруссии.

Малочисленность и дисперсность препятствовали изучению цыган. В некоторых случаях мы наблюдаем игнорирование самого факта их присутствия на изучаемой территории. Это можно проследить на примере статистических сборников второй половины XIX в. В таких авторитетных изданиях как «Атлас народонаселения ЗападноРусского края по вероисповеданиям» (Риттих, 1864) и историко-литературном журнале «Вестник Юго-Западной и Западной России» (Лебедкин, 1862) мы не обнаружим информацию о цыганах белорусских и украинских губерний.

В этих условиях диссонансом стали некоторые публицистические работы, в которых представлен материал об истории и повседневной жизни белорусских цыган второй половины XIX в. (Шпилевский, 1858). С этого времени исследователи сконцентрировали свое внимание на этнографических, культурологических, лингвистических аспектах, в то время как исторический компонент был либо отодвинут на второй план, либо вовсе выпал из поля зрения исследователей. Однако их работа позволила закрепить представление о цыганах в границах определенного историко-культурного ландшафофта современной Беларуси. 
В 1920-х - начале 1930-х гг. исследователи обратились к изучению истории малых народов СССР, в частности - цыган в Белорусской ССР. Интерес был продиктован проводимой местными властями политикой «белорусизации» - формирования и развития белорусской культуры и культуры этнодисперсных групп под контролем Советской власти. На этом фоне следует выделить статью Д. Довгялы (Даўгяла, 1926) о цыганах на белорусских землях в период Великого княжества Литовского и краткий очерк профессора Белорусского государственного университета И.А. Себрова (Сербаў, 1926). Эти работы заложили своего рода историографическую традицию - рассматривать историю цыган на территории Беларуси преимущественно в период вхождения ее в состав Великого княжества Литовского и Речи Посполитой.

Эту традицию поддержали и развили белорусские историки конца 1980-х - начала 2000-х гг. Возрождение интереса к прошлому этнических меньшинств было вызвано различными факторами. С одной стороны, исследователи обратились к теме, которая в советский период фактически табуировалась: можно было изучать лишь так называемые титульные народы. С другой стороны, сказался общественный запрос на изучение событий из жизни немцев, евреев, корейцев и других - представители этих народов хотели знать свою историю в границах Российской империи - СССР. Не последнюю роль в некоторых бывших союзных республиках сыграли процессы формирования собственной новой национальной идентичности. Однако белорусские исследователи останавливались преимущественно на границах Великого Княжества Литовского и Речи Посполитой (Карашчанка, 1989; Калінін, 1994; Сосна, 1997; Дучыц, 2003; Карашчанка, 2007; Зиневич, 2009; Захаркевич, 2006; Навагродскі \& Захаркевіч, 2017).

Отдельные аспекты истории белорусских цыган в последнее время нашли свое отражение в научных публикациях российских исследователей. В коллективной монографиии «Цыгане» они упоминаются в связи с процессом этногенеза отдельных дисперсных групп (2018). В некоторых статьях рассматриваются в общем контексте взаимоотношений царской администрации и цыганского мира конца XVIII - первой половины XIX в. (Shaidurov, 2018; Shaidurov et al., 2020).

Подводя итог, можно с уверенностью констатировать факт, что до сих пор нет серьезных работ, посвященных истории белорусских цыган в XIX - начале XX в. Это подтверждает содержание историографической части одного из последних обобщающих трудов, посвященного истории и культуре цыган России (Деметер \& Черных, 2018, с. 927). 


\section{ЦЫГАНЕ И ЗЕМЛЕУСТРОЙСТВО В БЕЛОРУССКИХ ГУБЕРНИЯХ}

В последней трети XVIII - первой четверти XIX в. предпринимались неоднократные попытки превратить цыган России в оседлое население, приписав их в разряд государственных крестьян в сельской местности или кооптировав в мещанские, купеческие общества в городах. Несмотря на все проводившиеся мероприятия, подавляющая часть лишь формально становилась оседлой, сохраняя традиционный образ жизни. Только в отдельных регионах (Выборгская губерния и Великое княжество Финляндское, Сибирь) властям удалось добиться того, что большая часть местного цыганского населения в силу исторического прошлого либо по объективным причинам вела оседлый образ жизни (Шайдуров и др., 2020, с. 140). Введение репрессивных мер - в отношении цыган, а также местных властей, помещиков - не могло переломить ситуацию.

Кампания по борьбе с бродяжничеством, инициированная Николаем I в 1839 г., затронула места традиционного проживания цыган белорусские губернии. Надо сказать, что уже в XVIII в. белорусские цыгане вели преимущественно оседлый образ жизни. Внутренняя жизнь цыганского мира регламентировалась принципами самоуправления, которые контролировались местными магнатами. Экономическое благосостояние верхушки базировалось на текстильных мануфактурах. Следовательно, эта часть цыганского сообщества шла по пути добровольной эмансипации. Однако кризис Речи Посполитой спровоцировал изменение сложившейся ситуации. Результатом стал исход части цыганских таборов в Валахию, Молдавию, Сибирь. По данным на начало XIX в., в белорусско-литовских губерниях проживало около $9 \%$ цыган Российской империи, учтенных ревизией 1797 г. (Shaidurov, 2017, c. 2111-2112).

Гродненская губерния была одним из традиционных мест проживания цыган с XVI в. Местечко Мир было своего рода их столицей в Беларуси. Пользуясь покровительством Радзивиллов, цыгане смогли прочно здесь обосноваться (Шпилевский, 1858, с. 72). Во второй половине XVIII - первой трети XIX в. цыгане вновь вернулись к кочевому образу жизни, который в правящих кругах Российской империи квалифицировали не иначе как бродяжничество.

Данные полицейского учета позволяют представить общую картину на Гродненщине. Согласно им, в городах и селениях губернии числилось 114 мужчин и 95 женщин. Только 9 семей (26 душ м.п.) на 1839 г. вели оседлый образ жизни. В отлучке находилось на тот 
момент по паспортам 10, без паспортов 67 мужчин. На месте приписки было только 11 человек (РГИА, 1849а, л. 2).

В 1840 г. Гродненская палата государственных имуществ была вовлечена в реализацию очередного плана по превращению цыган в оседлое население. Первым шагом стало их подчинение власти местных окружных начальников, призванных не допустить «непрестанных их побегов» (РГИА, 1849а, л. 3). Согласно донесению от 12 ноября 1841 г., 17 цыганских семей, состоящих из 25 мужчин и 23 женщин, были причислены в различные казенные имения и лесничества. Две семьи, Михаила и Лаврентия Рутковских (9 человек), числились за Пружанским округом, три семьи Томашевичей (11 мужчин и 10 женщин) были направлены в разные селения Лидского округа. Оставшиеся 12 семей были записаны за населенными пунктами Слонимского округа. Из дополнения к ведомости следует, что, помимо помянутых семей, в ревизских сказках по Гродненской губернии числятся еще 18 семейств, которые находились в бегах (РГИА, 1849а, л. 6). Уровень обеспеченности приписанных цыган был катастрофическим: только семейство Иосифа Томашевича (3 мужчин и 2 женщины) имели хозяйство, занимаясь хлебопашеством. Для прочих Могилевская палата намеревалась испрашивать положенную по закону ссуду (Там же).

Гродненские цыгане в основной своей массе негативно отнеслись к стремлению властей ограничить их перемещение. Как свидетельствуют отчетные документы, «причисленные к казенным селениям цыгане... по водворении из оных самовольно отлучились и оказываются неспособными к оседлой жизни» (РГИА, 1849а, л. 9). Подобная ситуация была скорее правилом, чем исключением. Позиция петербургских чиновников в отношении таких людей категорична: изобличенных после приписки к казенным селениям в бродяжничестве следовало предавать суду (РГИА, 1849а, л. 9 об.). Юридически это право местных властей базировалось на Высочайшем указе Николая Первого от 13 марта 1839 г. и указе Сената от 24 апреля того же года (ПС3-II, т. 14, № 12 104).

В 1843 г. повсеместно собирались данные о первых результатах кампании. Сведения, представленные в Санкт-Петербург Гродненской палатой, казалось бы, свидетельствовали о некотором успехе властей. Согласно ведомости, чиновникам удалось выявить и приписать к казенным селениям в общей сложности 34 семейства в составе 227 человек (120 м.п. и 107 ж.п.). Руководствуясь циркулярами, они стремились не допустить концентрации цыган в одном месте, 
а потому семьи приписывались к разным селениям староств и лесничеств. Если в 1841 г. география была достаточно ограниченной, то теперь стала более широкой (см. табл. 1).

\section{М.п. Ж.п.}

\section{Гродненский уезд}

Семейство Юстина Иосифова Томашевича

$\begin{array}{ll}8 & 8 \\ 4 & 2 \\ 3 & 4 \\ 2 & 2 \\ 4 & 4\end{array}$

Семейство Антона Иосифова Касперовича

Семейство Станислава Матвеева Касперовича

4

Семейство Иосифа Томашевича

2

Семейство Юстина Юрьева Томашевича

\section{Лидский уезд}

Семейство Кузьмы Касперовича

Семейство Петра Губаревича

Семейство Франца Рутковского

Семейство Викентия Флорияновича

Семейство Андрея Урбановича

Семейство Антона Касперовича

Семейство Александра Ротковского

Семейство Игнатия Томашевича

Семейство Антона Белявского

Семейство Петра Марцинкевича

Семейство Иосифа Козловского

$\begin{array}{ll}5 & 4 \\ 4 & 2 \\ 6 & 5 \\ 4 & 2 \\ 3 & 4 \\ 2 & 4 \\ 2 & 2 \\ 8 & 3 \\ 1 & 3 \\ 2 & 4 \\ 1 & 0 \\ 1 & 3\end{array}$

Семейство Франца Стефановича

\section{Слонимский уезд}

Семейство Казимира Брилевича

Семейство Иосифа Брилевича

Семейство Игнатия Брилевича

Семейство Фомы Брилевича

Семейство Антона Малевича

$\begin{array}{ll}5 & 5 \\ 6 & 4 \\ 3 & 2 \\ 4 & 3 \\ 3 & 4\end{array}$

\section{Новогрудский уезд}

Семейство Александра Василевского

Семейство Кузьмы Врублевского

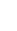
2 3

Семейство Ивана Врублевского

$\begin{array}{ll}1 & 1 \\ 5 & 2 \\ 6 & 4\end{array}$


Семейство Иосифа Громановича

Семейство Леона Соколовского

Кобринский уезд

\begin{tabular}{lll}
\hline Семейство Михаила Васильева Рутковского & 3 & 6 \\
Семейство Якова Войтехова Гловацкого & 3 & 5 \\
Семейство Якова Иосифова Рутковского & 0 & 3 \\
Семейство Феликса Темеровича & 4 & 1 \\
Семейство Доминика Казимирова Рутковского & 4 & 2 \\
Семейство Игнатия Станиславова Хведаревича & 1 & 2 \\
\hline
\end{tabular}

Пружанский уезд

Семейство Ивана Волоши

Таблица 1. Размещение цыган в казенных селениях

Гродненской губернии, январь 1843 г. (РГИА, 1849а, лл. 21 об. - 26)

Table 1. Placement of Gypsies in the Government Villages of Grodno Province, January 1843.

В общей сложности окружные управления ассигновали из собственных средств пособия для 11 семей. В некоторых случаях было предписано выделить лес для строительства жилых и хозяйственных построек. Однако это не могло удержать цыган на новом месте. Так, в августе 1843 г. Слонимское окружное управление доносило в Гродненскую палату государственных имуществ о невыдаче приписанным цыганам полагающихся денег. Причинами тому были неспособность к хлебопашеству и отлучка, в бегах числилось 3 семейства.

Цыгане, которые проживали в своих селениях, занимались хозяйством, ремеслом (наибольшее распространение получило изготовление обуви, в первую очередь, сапог). Те, кто не получил еще земельного надела, должны были искать заработок на стороне. Включенность в кустарную промышленность носила единичный характер: так, Игнатий Хведаревич являлся работником кирпичного завода в Кобрине (РГИА, 1849а, л. 26).

Казенные пособия должны были способствовать закреплению цыган в селениях. Их размер для цыган Гродненской губернии был определен в 28 руб. 58 коп. серебром либо 14 руб. 29 коп. серебром и лесом (РГИА, 1849а, л. 40). Всего за 1844 г. из казны цыганам выде- 
лили 229 руб. 58 коп. серебром и 66 руб. лесом. Эти пособия получили 13 семей (РГИА, 1849а, л. 60).

Встречались сбои. В конце 1843 - середине 1844 г. между Слонимским окружным управлением и Гродненской палатой государственных имуществ завязалась переписка по случаю отказа цыган Казимира и Игнатия Брилевичей от полагавшихся им пособий в размере 50 руб. асс. на семью. Главы семейств приняли на себя обязательство соорудить дома и прочие хозяйственные постройки за собственный счет. Они уверили местные власти в том, что будут «за отведенную под усадьбу и огород землю положенный по инвентарю чинш и казенные подати платить аккуратно» (РГИА, 1849а, л. 49 об.).

Подобного рода позиция имела под собой определенные основания. Некоторые гродненские цыгане в результате реализации кампании 1839 г. были насильственно причислены в селения. Например, упомянутый Казимир Брилевич, ранее причисленный к мещанскому обществу г. Слонима и занимавшийся «торговой промышленностью». В октябре 1844 г. он обратился к властям с просьбой о перечислении его в прежнее состояние. Факт отказа в принятии ассигнованной ему от Казны денежной ссуды и строевого леса в значительной степени поспособствовали положительному решению. В марте 1845 г. губернская Палата государственных имуществ обратилась во Второй департамент Министерства государственных имуществ с просьбой удовлетворить прошение Брилевича.

Некоторые согласились обзавестись крепким хозяйством. Примером могут служить оказавшиеся в деревне Проневичи Бельского уезда семьи Касперовичей, попавшие в неприятную ситуацию. Получив от окружного управления деньги на возведение дома и хозяйственных построек, они начали строительство «по изданному для сего планам и фасадам». Это потребовало привлечения пильщиков и плотников, результатом чего стало резкое удорожание работ. Летом 1846 г. строительство было остановлено. Не оказалось средств на приобретение нужных сельскохозяйственных орудий, рабочего и домашнего скота. Цыгане обратились к местному начальству с просьбой о выделении дополнительных денег. В октябре того же года Касперовичам было выделено дополнительно 20 руб. серебром (РГИА, 1849а, л. 76). Однако эти деньги, как свидетельствуют документы, они смогли получить лишь в середине 1850 г. (РГИА, 1849а, л. 97).

Одним из мест проживания цыган во второй четверти XIX в. была Могилевская губерния. Некоторые семьи крайне положительно отнеслись к мероприятиям, которые проводились Министерством государ- 
ственных имуществ по пути реализации поручения императора. В июле 1841 г. министр П.Д. Киселев совершил осмотр территории. Его приездом воспользовался цыган Давыд Андреевич Барановский (примерно 1796 года рождения), подавший прошение. Как следует из документа, большая часть его жизни была связана со служением «первоначально у бывшего владельца Горецкого имения графа Сологуба, а напоследок у разных знаменитых господ» (РГИА, 1843, л. 4). Давыд Барановский уверенно заявлял, что оставался «совершенно чуждым кочующей жизни общества моего сословия» (РГИА, 1843, л. 4). В достаточно зрелом возрасте (1836 г.) он обзавелся собственным домом. Имея многочисленное семейство, состоявшее из жены, дочери и пяти сыновей, цыган вел хозяйство, которое было главным источником дохода. Сохранился перечень имевшегося у него скота: коров дойных - 3, телят - 4, лошадей рабочих - 3, жеребят - 2, овец - 7, свиней - 15, кур - 17, гусей - 14 (РГИА, 1843, л. 6). Даже по меркам начала XX в. Давыд Барановский был крепким хозяином, различные виды домашней живности свидетельствуют об оседлости их владельца. Однако для поддержания благосостояния главе семейства не хватало земли. Именно ее он добивался у П.Д. Киселева в своем прошении.

В 1842-1843 гг. дело Давыда Барановского получило развитие. Не последнюю роль в этом сыграли столичные чиновники, которые видели в стремлении могилевского цыгана получить землю успех проводимой ими кампании.Прошение было первоначально передано на рассмотрение начальства Горыгорецкой земледельческой школы, в ее ведении находилась Воловая пустошь, из состава которой испрашивались земли. Администрация школы первоначально отказала Давыду Барановскому в переселении, так как он вместе с семейством был записан по ревизии в местечке Горки, принадлежащем школе; ему предложили получить земельный надел по месту приписки. Однако позднее ходатайство направили в Могилевскую палату государственных имуществ, в ведении которой находились земли пустоши. Решение вопроса в результате передали мстиславскому окружному начальнику. По его сведениям, земля числилась праздной, «к представлению из оной в пользование Барановскому просимого им количества нет никаких препятствий» (РГИА, 1843, л. 13).

Однако возникло непредвиденное обстоятельство: пустошь интересовала и местных крестьян, которые вознамерились взять землю в аренду, с платежом 20 руб. 80 коп. асс. в год. В своем донесении в Могилев окружной начальник склонялся в пользу крестьян, «признавая выгоднейшим... дать крестьянам, а платеж обратить 
на уплату податей за малолетних крестьянских сирот того имения, а цыгану Барановскому отказать» (РГИА, 1843, л. 13 об. - 14). Чиновник поддержал позицию администрации Земледельческой школы, настаивая на выделении просителю земли на ее территории. Дополнительным аргументом, по его мнению, стал факт выделения здесь других земельных наделов для водворения цыган, «коих несколько семейств уже и водворены» (РГИА, 1843, л. 14).

Руководство губернской Палаты государственных имуществ оказалась в непростой ситуации, но нарушать наложенную на прошение Давыда Барановского резолюцию «сделать надлежащее распоряжение о наделении его просимой землей для прочного водворения с семейством» (РГИА, 1843, л. 14 об.) не стало. Было принято решение, что «нет оснований давать более преимуществ крестьянам, имеющим свои удельные участки земли, пред цыганом Барановским, требующим попечений Правительства, чтобы приучить его к постоянной оседлости» (РГИА, 1843, л. 15 об.). К январю 1844 г. все формальности были урегулированы - Давыд Барановский получил просимые земли и был приписан в ведение Могилевской палаты государственных имуществ (РГИА, 1843, л. 20).

В 1847 г. Давыд Барановский заявил о своем праве на получение казенной помощи. Выше уже отмечалось, что он имел различный скот и домашнюю птицу. Этот факт не давал ему возможность претендовать на получение денежного пособия. Однако им было подано прошение об отпуске леса на постройку дома (на 60 руб. серебром). Просимая сумма пятикратно превышала пособие, предусмотренное законом. На этом основании Могилевская палата государственных имуществ приняла решение в духе упомянутого циркуляра П.Д. Киселева от 27 марта 1840 г.: пособие в размере 50 руб. асс. (14 руб. 29 коп. серебром) выделялось исключительно на приобретение строевого леса (РГИА, 1849b, л. 20 об.).

Как следует из сохранившихся архивных документов, Давыд Барановский был не единственным представителем цыганского общества, кто изъявил желание получить земельный надел и вести оседлый образ жизни. На начало 1846 г. в ведении Конторы Горыгорецкой земледельческой школы числились восемь цыганских семей (Алексея Григорьева, Петра Ермолаева, Елисея Алексеева, Ивана Андреева, Ивана Борисова, Венедикта Павлова, Ермолая Васильева и Степана Лукьянова), состоящие из 20 мужчин и 28 женщин (РГИА, 1849b, л. 1 - 1 об.).

К середине 1840-х гг. была разработана серия поощрительных мер со стороны правительства, чем цыгане пользовались. Так, в циркуляре 
Министра государственных имуществ П.Д. Киселева от 27 марта 1840 г. предписывалось оказывать им различное материальное вспомоществование. В частности, следовало выделять по 50 руб. асс. из расчета на одну семью.

В своем донесении во Второй департамент Государственных имуществ Могилевская палата в сентябре 1846 г. сообщала, что цыгане просили выделить им из Казны денежное пособие «на первоначальное обзаведение и отпуск леса для постройки домов» (РГИА, 1849b, л. 1 об.). Ведомство при этом постаралось увязать факт предоставления денежного пособия и строевого леса с фактическим прикреплением семей к земельным наделам. К этому времени шесть из восьми семей высказали согласие поселиться в фольварках, принадлежавших Наталину и Никодимову и находившихся в ведении Могилевской палаты государственных имуществ (РГИА, 1849b, л. 2 об.). Внесение данных в ревизские сказки открывало дорогу к получению заветного пособия.

В сентябре того же года в результате межведомственной переписки в Министерстве государственных имуществ было принято решение о выделении Могилевской палате из средств, определенных к выдаче пособий крестьянам, переселявшимся в многоземельные губернии, 85 руб. 84 коп. серебром - для выдачи шести цыганским семействам Могилевской губернии пособия.Испрашивая полагавшиеся им деньги, цыгане намеревались в течение весны - осени 1846 г. построить жилые постройки и обзавестись каким-то хозяйством. Однако неторопливость бюрократической машины грозила остаться накануне зимы без крыши над головой.

Для решения проблемы нуждающиеся использовали все возможные средства, в том числе проезд П.Д. Киселева через Горыгорецкое имение. Графу было подано прошение «о скорейшем отводе им земель и оказании пособия лесом и деньгами» (РГИА, 1849b, л. 7). Министру пришлось, как и в случае с Барановским, применить «ручное управление», поручив люстратору и окружному начальнику выделить цыганам «смотря по состоянию каждого семейства усадебные, пахотные и сенокосные земли, и по утверждению Палатой внесли в Люстрационный инвентарь платежа за те земли согласно особому постановлению... о цыганах» (РГИА, 1849b, л. 7 - 7 об.). Помощь в водворении должна была исходить не только от казенных ведомств, но и сельских обществ, которым предписывалось осуществить возведение жилых домов и хозяйственных построек.

Семейства Ивана Борисова и Ермолая Васильева оказались в особом положении. Они изъявили желание поселиться в деревне Каролевке имения той же земледельческой школы. Однако чинов- 
ники, выполняя поручение П.Д. Киселева, о нихзабыли. 31 октября 1846 г. Могилевская палата сообщала в Санкт-Петербург, что на два семейства денежные средства до сих пор не запрошены, просило дать распоряжение об их выделении.

К концу апреля 1847 г. была завершена процедура межевания земельных наделов и внесения их в Люстрационный инвентарь. Участки согласились принять только семьиз восьми семей: восьмаясостояла из двух человек (1 м.п. и 1 ж.п.) и, по данным губернского люстратора, отказалась принять обмежованную часть по причине «малосемейственности», осталась в положении бобылей (РГИА, 1849b, л. 22).

Процесс выделения цыганам Могилевской губернии законного пособия в размере 14 руб. 29 коп. серебром растянулся. Достоверно известно, что 4 июня, 30 сентября 1849 г., 19 января, 16 мая 1850 г., 24 февраля, 30 июня, 15 октября, 31 декабря 1851 г., 30 июня 1852 г., 14 апреля, 27 августа, 28 декабря 1853 г., 29 сентября 1854 г. (РГИА, 1849b, л. 30 - 43)Второй департамент государственных имуществ направлял запросы в Первый департамент: «какое сделано распоряжение к отпуску в ведение Могилевской палаты государственных имуществ денег в пособие семи семействам цыган, водворенным в казенном Горыгорецком имении» (РГИА, 1849b, л. 43). Только 30 ноября 1854 г. от Могилевской палаты государственных имуществ получили ответ, согласно которому «означенные 8 семейств цыган... денежным пособием на обзаведение хозяйством... не воспользовались» (РГИА, 1849b, л. 44 об.), поскольку требуемая сумма Министерством государственных имуществ выделена не была.

Последовала внутриведомственная проверка. Могилевская палата государственных имуществ, в частности, направила во Второй департамент запрос: «которого года и числа и за каким номером дано ей предписание Первого департамента по предмету назначения денежного пособия цыганам» (РГИА, 1849b, л. 48 - 48 об.). Выяснилось, что подобное предписание было дано еще 21 декабря 1853 г.

В сентябре 1855 г. Могилевская палата подтвердила перед Вторым департаментом факт непредоставления цыганским семьям положенного пособия. И мотивировала отсутствие необходимости его выделения в текущей ситуации: полученные в результате люстрации земельные наделы цыгане не обрабатывали и положенного с них оброка не платили. Вскоре, при исправлении нарезки земель по люстрации, они были лишены участков. В результате, как отмечало ведомство, «продолжили вести кочующую жизнь» (РГИА, 1849b, л. 50 об.). 
Местные крестьяне в вопросе инкорпорирования цыган в свой состав занимали негативную позицию. Со слов чиновников, «общество крестьян не ручается в верной и бездоимочной уплате того пособия, в случае бы выдачи такового, тем более, что на них и без того числится значительная недоимка» (РГИА, 1849b, л. 50 об.).

Налицо цепочка взаимосвязанных фактов, объясняющая очередной провал попытки властей превратить цыган в оседлое население: невыплата пособия - невозможность купить скот, инвентарь для обработки земли - обнищание - возвращение к традиционному образу жизни.

\section{ВЫВОДЫ}

Таким образом, новая попытка русского правительства «посадить» цыган на землю была обставлена рядом покровительственных мер, которые включали выделение земельных наделов, предоставление финансовой и иной материальной помощи. Однако патерналистская политика в этот период в значительной степени оставалась на бумаге. Одной из основных причин тому стали различные формы латентного шовинизма. Чиновники на местах саботировали распоряжения из столицы, а крестьяне не были готовы к тому, чтобы видеть в цыганах равноправных членовобщества.

\section{БЛАГОДАРНОСТЬ}

Исследование выполнено в рамках проекта РФФИ № 20-09-00 092 «Цыганские сообщества России: формирование, этнокультурные особенности, взаимодействия с обществом и властью».

\section{Список литературы}

Czacki, T. (1810). O Tatarach [About Tatars]. DziennikWileński [Vilnius Daily] (In Polish).

Czacki, T. (1835). O Cyganach [About Gypsies]. In Pomnikihistoriiiliteraturypolskiej [Monuments of Polish history and literature] (Vol. 2, pp. 59-86). Kraków (In Polish).

Czacki, T. (1845). O Cyganach [About Gypsies]. In Dzieła. Zebraneiwydaneprzez Hr. E. Raczyńskiego [Works. Collected and published by Hr. E. Raczyński]: Vol.III. Poznań (In Polish).

Czacki, T. (1807a). O Żydach [About Jews]. Wilno (In Polish).

Czacki, T. (1807b). O ŻydachiKaraimach [About Jews and Karaites]. DziennikWileński [Vilnius Daily] (In Polish). 
Shaidurov, V. (2017). On the History of the Roma in the Russian Empire (second half of the 18th - first quarter of the 19th century). BylyeGody, 46(4). doi: 10.13187/ bg.2017.4.1207

Shaidurov, V. (2018). Gypsies in the Russian Empire: Theories and practices addressing their situation during the eighteenth and first half of the nineteenth century. Romani Studies, 28(2), 195-217. doi: 10.3828/rs.2018.8

Shaidurov, V., Sinko, G., \&Goncharov, Y. (2020). Gypsies in Siberia: Resettlement, Family and Economic Activity between the 18th and first half of the 19th century (Historical Aspect). BylyeGody, 56(2). doi: 10.13187/bg.2020.2.463

Данилович, И. (1826а). Историческое и этнографическое исследование о цыганах. Северный архив, 19(1), 64-79.

Данилович, И. (1826b). Историческое и этнографическое исследование о цыганах. Северный архив, 19(2), 180-195.

Данилович, И. (1826c). Историческое и этнографическое исследование о цыганах. Северный архив, 19(3), 276-290.

Данилович, И. (1826d). Историческое и этнографическое исследование о цыганах. Северный архив, 19(4), 384-403.

Данилович, И. (1826е). Историческое и этнографическое исследование о цыганах. Северный архив, 20(5), 73-86.

Данилович, И. (1826f). Историческое и этнографическое исследование о цыганах. Северный архив, 20(6), 184-208.

Даўгяла, 3. I. (1926). Цыганы на Беларусі [GypsiesinBelarus]. Нашкрай, (12), 25-34 (In Belarusian).

Дучыц, Л. У. (2003). ЗгісторыіцыганоўБеларусі [From the history of the gypsies of Belarus]. Беларускіzістарычнычасопіс [Belarusian Historical fournal], (3), 45-49 (In Belarusian).

Захаркевич, С. А. (2006). Государственная политика по отношению к этническим меньшинствам Беларуси в XIV-XVIII в. ВеснікВіцебскагадзяржаўнагауніверcimэma, (1), 3-7.

Зиневич, Н. (2009). Институт цыганских королей в Речи Посполитой. В Гicmapbяграфія і крыніщы па гісторыігарадоў і пращэсаўурбанізащы у Беларусі (сс. 126138). Гродна.

Калінін, В. (1994). Цыганы на Беларусі [GypsiesinBelarus]. В 3 zicmopыяй на “Вы” [With a historyinthe «You»] (сc. 330-349). Мінск (InBelarusian).

Карашчанка, I. (1989). Цыганы. В ЭтнаграфіяБеларусі: Энщыклапедыя (сс. 522523).Мінск (InBelarusian).

Карашчанка, І. (2007). Цыганы. В ВялікаекнястваЛітоўскае: Энщькклапедыя (Т. 2, сс. 729-730). Мінск (InBelarusian).

Лебедкин, М. (1862). О племенном составе народонаселения Западного края Российской империи. Вестник Юго-Западной и Западной России, 2(IV), 1-33. 
Навагродскі, Т. А.\&Захаркевіч, С. А. (2017). ГістарычнасклаўшыясяэтнічныяменшасціБеларусі: Вопытпрыязнагасуіснавання ў еўрапейскайкраіне [HistoricallyformedethnicminoritiesofBelarus: Theexperienceoffriendlycoexistencein a Europeancountry]. В А. Г. Каханоўскі (Ред.), Этнічныяменшасиі у ЕўрапейскімСаюзе: Асноўныяправавыякрыніцы [EthnicminoritiesintheEuropeanUnion: Mainlegalsources]. Мінск (InBelarusian).

Полное собрание законов Российской империи. Издание II. Т. 14. № 12104 (1754).

Риттих, А. Ф. (1864). Атлас народонаселения Западно-Русского края по вероисповеданиям. Составлен при Министерстве внутренних дел в Канцелярии заведующего устройством православных церквей в западных губерниях. Санкт-Петербург.

Российский государственный исторический архив (РГИА) (1843). Ф. 384. On. 3. Д. 165.

Российский государственный исторический архив (РГИА) (1849a). Ф. 384. On. 4. Д. 524.

Российский государственный исторический архив (РГИА) (1849b). Ф. 384. On. 4. Д. 530.

Сербаў, I. А. (1926). Цыганы. Ведай сваю гісторыю [Gypsies. Know your story]. Маладыıараты [Young plowmen], (7), 14 (In Belarusian).

Сосна, У. (1997). СпробаасляніцьцыганоўБеларусіўканцыXVIIIст. -ПершайпаловеXIXст. [An attempt to defile the gypsies of Belarus in the late 18th century - The first half of the 19th century]. ВесціМіжнароднайакадэміівывучэннянацыянальныхменшасцей, (1), 35-36 (In Belarusian).

Цыгане (2018). Москва: Наука.

Шайдуров, В. Н., Новогродский, Т. А., Синько, Г. И.\&Захаркевич, С. А. (2020). Цыгане: из Беларуси в Сибирь (по документам и материалам XVIII - первой половины XIX в.). Bonросы истории, (10-1), 130-142. doi: 10.31166/ VoprosyIstorii202 010Statyi08

Шпилевский, П. М. (1858). Путешествие по Полесью и Белорусскому краю. Санкт-Петербург.

\section{References}

Czacki, T. (1810). O Tatarach [AboutTatars]. DziennikWileński [Vilnius Daily]. (In Polish).

Czacki, T. (1835). O Cyganach [About Gypsies]. In Pomnikihistoriiiliteraturypolskiej [Monuments of Polish history and literature] (Vol. 2, pp. 59-86). Kraków. (In Polish).

Czacki, T. (1845). O Cyganach [About Gypsies]. In Dzieła. Zebraneiwydaneprzez Hr. E. Raczyńskiego [Works. Collected and published by Hr. E. Raczyński]: Vol.III. Poznań. (In Polish).

Czacki, T. (1807a). O Żydach [About fews]. Wilno. (In Polish).

Czacki, T. (1807b). O ŻydachiKaraimach [About Jews and Karaites]. DziennikWileński[Vilnius Daily]. (In Polish). 
Shaidurov, V. (2017). On the History of the Roma in the Russian Empire (second half of the 18th - first quarter of the 19th century). BylyeGody, 46(4). doi: 10.13187/ bg.2017.4.1207

Shaidurov, V. (2018). Gypsies in the Russian Empire: Theories and practices addressing their situation during the eighteenth and first half of the nineteenth century. Romani Studies, 28(2), 195-217. doi: 10.3828/rs.2018.8

Shaidurov, V., Sinko, G. \&Goncharov, Y. (2020). Gypsies in Siberia: Resettlement, Family and Economic Activity between the 18th and first half of the 19th century (Historical Aspect). BylyeGody, 56(2). doi: 10.13187/bg.2020.2.463

Danilovich, I. (1826a). A Historical and Ethnographic Study of the Gypsies. The Northern Archives, 19(1), 64-79 (In Russian).

Danilovich, I. (1826b). A Historical and Ethnographic Study of the Gypsies. The Northern Archives, 19(2), 180-195 (In Russian).

Danilovich, I. (1826c). A Historical and Ethnographic Study of the Gypsies. The Northern Archives, 19(3), 276-290 (In Russian).

Danilovich, I. (1826d). A Historical and Ethnographic Study of the Gypsies. The Northern Archives, 19(4), 384-403 (In Russian).

Danilovich, I. (1826e). A Historical and Ethnographic Study of the Gypsies. The Northern Archives, 20(5), 73-86 (In Russian).

Danilovich, I. (1826f). A Historical and Ethnographic Study of the Gypsies. The Northern Archives, 20(6), 184-208 (In Russian).

Daugyala, Z. I. (1926). Gypsies in Belarus. Our Land, (12), 25-34 (In Belarusian).

Duchyts, L. U. (2003). From the history of the gypsies of Belarus. Belarusian Historical fournal, (3), 45-49 (In Belarusian).

Zakharkevich, S. A. (2006). State policy towards ethnic minorities in Belarus in the $14^{\text {th }}-$ 18th centuries. Bulletin of Vitebsk State University, (1), 3-7 (In Russian).

Zinevich, N. (2009). The Institute of Roma Kings in the Rzeczpospolita. In Historiography and sources on the history of cities and urbanization processes in Belarus (pp. 126-138). Grodno (In Russian).

Kalinin, V. (1994). Gypsies in Belarus. In With a history in the «You» (pp. 330-349). Minsk (In Belarusian).

Karashchanka, I. (1989). Gypsies. In Ethnography of Belarus: Encyclopedia (pp. 522-523). Minsk (In Belarusian).

Karashchanka, I. (2007). Gypsies. In Grand Duchy of Lithuania: Encyclopedia (Vol. 2, pp. 729730). Minsk (In Belarusian).

Lebedkin, M. (1862). On the tribal composition of the population of the Western Region of the Russian Empire. Bulletin of Southwestern and Western Russia, 2(IV), 1-33 (In Russian).

Navagrodski, T. A.\&Zakharkevich, S. A. (2017). Historically formed ethnic minorities of Belarus: The experience of friendly coexistence in a European country. In A. G. 
Kakhanouski (Ed.), Ethnic minorities in the European Union: Main legal sources. Minsk (In Belarusian).

Complete Collection of Laws of the Russian Empire. Edition II. Vol. 14. № 12104 (1754) (In Russian).

Rittich, A. F. (1864). Atlas of the Population of the Western Russian Territory by Religion. Compiled under the Ministry of Internal Affairs in the Office of the Superintendent of Orthodox Churches in Western Provinces. St. Petersburg (In Russian).

Russian State Historical Archive (RSHA) (1843). F. 384. Inv. 3. C. 165 (In Russian).

Russian State Historical Archive (RSHA) (1849a). F. 384. Inv. 4. C. 524 (In Russian).

Russian State Historical Archive (RSHA) (1849b). F. 384. Inv. 4. C. 530 (In Russian).

Serbau, I. A. (1926). Gypsies. Know your story. Young plowmen, (7), 14 (In Belarusian).

Sosna, U. (1997). An attempt to defile the gypsies of Belarus in the late 18th century -The first half of the 19th century. Lead the International Academy for the Study of National Minorities, (1), 35-36. (In Belarusian).

Gypsies (2018). Moscow: Nauka (In Russian).

Shaydurov, V. N., Novogrodsky, T. A., Sinko, G. I.\&Zakharkevich, S. A. (2020). Roma: From Belarus to Siberia (based on documents and materials from the 18th century and the first half of the 19th century). Issues in History, (10-1), 130-142. doi: 10.31166/ VoprosyIstorii202 010Statyi08 (In Russian).

Shpilevsky, P. M. (1858). Journey through Polesye and the Belarusian region. St. Petersburg (InRussian). 